\title{
Jurist-Diction
}

Volume 3 No. 5, September 2020

\section{Kerjasama Dokter dengan Pedagang Besar Farmasi Terkait Pemberian Obat Pasien}

\author{
Herninta Lagoon Fatika \\ fafaherninta@gmail.com \\ Universitas Airlangga
}

\author{
How to cite: \\ Herninta Lagoon Fatika, \\ 'Kerjasama Dokter dengan \\ Pedagang Besar Farmasi \\ Terkait Pemberian Obat Pasien' \\ (2020) Vol. 3 No. 5 Jurist- \\ Diction. \\ Histori artikel: \\ Submit 17 Juli 2020; \\ Diterima 14 Agustus 2020; \\ Diterbitkan 1 September 2020. \\ DOI: \\ 10.20473/jd.v3i5.21979
}

\begin{abstract}
Abstrak
Permasalahan pidana menjadi permasalahan yang serius di beberapa negara termasuk di Indonesia, tanpa terkecuali dalam bidang kesehatan seperti kerjasama antara dokter dengan pedagang besar farmasi terkait pemberian obat terhadap pasien dimana kerjasama ini mengutamakan keuntungan masing-masing pihak yang melanggar kode etik dan juga peraturan hukum di Indonesia. Pada Pasal 3 Kode Etik Kedokteran Indonesia (KODEKI). Ketentuan ini juga diatur dalam Peraturan Menteri Kesehatan Republik Indonesia Nomor 58 Tahun 2016 tentang Sponsorship Bagi Tenaga Kesehatan yang menjelaskan beberapa kerjasama itu diperbolehkan, akan tetapi ketentuan ini bertentangan dengan apa yang diatur dalam Peraturan Menteri Kesehatan Republik Indonesia Nomor 14 Tahun 2014 Tentang Pengendalian Gratifikasi di Lingkungan Kementerian Kesehatan jo Pasal 12B UndangUndang Nomor 5 Undang-undang No.31 Tahun 1999 jo Undangundang No.20 Tahun 2001 Tentang Pemberantasan Tindak Pidana Korupsi, dan Kode Etik International Pharmaceutical Manufacturers Group (IPMG) 2019 yang diratifikasi oleh Indonesia. Tujuan dari penulisan penelitian ini adalah untuk menganalisis kerjasama antara dokter dengan pedagang besar farmasi dalam hal pemberian obat pada pasien yang dapat dikualifikasikan sebagai perbuatan pidana dan pertanggungjawaban pidana yang diberikan ditinjau dari aspek etik dan hukum. Kesimpulan dari penelitian ini adalah kerjasama antara dokter dengan pedagang besar farmasi yang dikualifikasikan perbuatan pidana adalah kerjasama yang mementingkan salah satu pihak atau kedua belah pihak untuk mendapatkan keuntungan dan menimbulkan akibat hukum yaitu kerjasama yang melanggar etik dan hukum di Indonesia seperti gratifikasi.

Kata Kunci: Sponsorship; Dokter; Pedagang Besar Farmasi.
\end{abstract}

\section{Pendahuluan}

Implementasi pelayanan kesehatan di Indonesia masih kurang hal ini dikarenakan tenaga kesehatan kurang menerapkan rasa profesionalitas dan melaksanakan pedoman etik yang dimilikinya. Hal ini diilustrasikan menurut data kementerian kesehatan dan aturan mengenai Surat Edaran Nomor $\mathrm{KF}$ / MENKES/167/III/2014 Tentang Pengadaan Obat Berdasarkan Katalog Elektronik 
(E-Catalogue) bahwa terdapat pelayanan kesehatan yang berindikasikan melanggar hukum.

Pelayanan kesehatan yang berindikasikan melanggar hukum itu berupa kerjasama yang dilakukan oleh dokter dengan pedagang besar farmasi (PBF). Tenaga kesehatan seperti dokter maupun PBF memiliki kode etik tersendiri. Namun, hubungan yang terbilang biasa saja dapat menimbulkan kecenderungan mengarah kepada hal yang dapat menguntungkan kedua belah pihak. Ketika berobat ke dokter besar keinginan pasien adalah untuk sembuh dan dalam situasi ini pasien tidak tahu penyakit yang diderita yang berlaku juga tidak tahu pilihat obat yang tepat untuk berobat. Sehingga pasien melakukan pengobatan ke dokter untuk berobat dan mendiagnosis yang dideritanya dan menerima pemberian resep obat yang diberikan oleh dokter. Dalam hubungan dokter dengan pasien inilah menyerahkan sepenuhnya pilihan obat untuk kesembuhan kepada dokter, yang kemudian memberikan resep obat. ${ }^{1}$

Permasalahan ini juga menjadi isu adanya konflik norma dari sisi perspektif pasien dimana pasien mengalami kerugian secara finansial dalam menerima resep obat yang diberikan oleh dokter. Hal ini berupa dokter memberikan resep dengan harga obat yang jauh diatas standar daripada harga yang lebih terjangkau walaupun dari sisi komposisi dan kandungan obat-obatannya itu sama pentingnya untuk kesembuhan pasien. Kejadian ini tidak hanya di rumah sakit umum daerah adapun rumah swasta yang melakukan kerjasama yang tidak sesuai dengan kaidah aturan perundangan-undangan dan kewenangannya antara dokter dengan PBF di Indonesia. ${ }^{2}$ Sedangkan, dalam aturan Pasal 3 Kode Etik Kedokteran Indonesia. Dimana Sesuai dengan pasal tersebut sifat dagang yang dalam segala situasi mencari keuntungan sebanyak-banyaknya, tidak boleh dipakai karena perbuatan tersebut bertentangan

\footnotetext{
1 Hasbullah thabrany. Biaya Obat Bagi Peserta Askes di Berbagai Klinik RSCM diakses dari http://staff.ui.ac.id/system/files/users/hasbulah/material/biayaobatpesertaaskesdirscm.pdf

2 Nasrul Wathoni, 'Lingkaran Terlarang Perusahaan Farmasi-MedRep-Praktisi Kesehatan dalam Dunia Distribusi Obat', 2016, <www.Kompasiana.com>, diakses tanggal 23 September 2019.
} 
dengan etika kedokteran. ${ }^{3}$ Serta, dalam praktiknya dilarang dalam Undang-Undang Nomor 29 Tahun 2004 Tentang Praktik Kedokteran. ${ }^{4}$ Namun, dalam PMK Nomor 1148/MENKES/PER/VI/2011 Tentang Pedagang Besar Farmasi belum dijelaskan secara detail mengenai ketentuan PBF bekerja sama dengan dokter dalam hal pemberian obat terhadap pasien. Selain itu, juga dalam ketentuan PMK Nomor 58 Tahun 2016 Tentang Sponsorship Bagi Tenaga Kesehatan bahwa dokter sebagai tenaga kesehatan boleh saja menjadi media promosi terkait obat dari PBF namun tidak secara rinci berapa persentasenya. ${ }^{5}$

Pemanfaatan dokter sebagai media promosi obat dalam Peraturan Menteri Kesehatan Republik Indonesia Nomor 58 Tahun 2016 Tentang Sponsorship bagi Tenaga Kesehatan boleh melakukan dengan catatan untuk kepentingan CPD (contunuing professional development) atau CME (continuing medical education). Namun, disisi lain PBF melakukan kerjasama yang tidak sehat yang akibatnya dapat merugikan pasien dalam pemberian obat. ${ }^{6}$ Dari permasalahan seperti tersebut di atas, maka dalam hal ini saya melakukan penelitian dan menganlisis yang lebih dalam terhadap aspek peraturan hukum di Indonesia pada praktek kerjasama pemberian obat terhadap pasien yang mengakibatkan ruginya pasien yang dilakukan oleh dokter dengan PBF tersebut.

\section{Rumusan Masalah}

1. Apakah kerjasama dokter dengan PBF yang mengakibatkan kerugian pasien dalam hal pemberian obat dapat dikualifikasikan sebagai perbuatan pidana?

2. Apakah kerjasama yang dilakukan oleh dokter dengan PBF yang mengakibatkan kerugian pasien dapat dipertanggungjawabkan secara hukum dan etik yang berlaku?

\footnotetext{
3 Lihat Kode Etik Ikatan Dokter Indonesia (IDI), Pasal 3.

4 Lihat Undang-Undang Nomor 24 Tahun 2009 Tentang Praktik Kedokteran.

5 Lihat ketentuan Peraturan Menteri Kesehatan Nomor 58 Tahun 2016 Tentang Sponsorship Bagi Tenaga Kesehatan.

6 ibid.
} 


\section{Kualifikasi Perbuatan Pidana dalam Kerjasama Dokter dengan Pedagang Besar Farmasi (PBF)}

Kerjasama yang dilakukan antara dokter dengan PBF itu ada yang diperbolehkan dan dilarang terkait dalam pemberian obat kepada pasien:

a. Kerjasama yang diperbolehkan

Kerjasama yang diperbolehkan antara dokter dengan PBF tidak terlepas dari prinsip pemberian sponsorship yang diatur pada Pasal 4 Ayat (1) PMK Nomor 58 Tahun 2016 tentang Sponsorship bagi Tenaga Kesehatan yang menyatakan bahwa "Sponshorship yang diberikan kepada Tenaga Kesehatan harus memenuhi prinsip:

a. tidak mempengaruhi independensi dalam pemberian pelayanan kesehatan;

b. tidak dalam bentuk uang atau setara uang;

c. tidak diberikan secara langsung kepada individu;

d. sesuai dengan bidang keahlian;

e. diberikan secara terbuka; dan

f. dikelola secara akuntabel dan transparan.

Terdapat pengecualian dalam Pasal 4 Peraturan Menteri Kesehatan Nomor 58 Tahun 2016 tentang Sponsorship bagi Tenaga Kesehatan yang menyatakan bahwa, "Dikecualikan dari ketentuan sebagaimana dimaksud pada ayat (1) huruf b dan huruf c, Sponsorship dapat diberikan berupa uang atau setara uang untuk honor bagi pembicara dan/atau moderator".

Hal ini diberi pengecualian dikarenakan seperti tujuan utama antara kerjasama dokter dengan PBF yaitu PBF memberikan secara terbuka mengenai pendanaan untuk penelitian dokter dimana dokter melakukan penelitian itu wajib berdasarkan Pasal 17 Kode Etik Kedokteran Indonesia ${ }^{8}$ yang menyatakan bahwa "Setiap dokter harus senantiasa mengikuti perkembangan ilmu pengetahuan dan teknologi kedokteran/kesehatan”.

Lebih lanjut dalam Pasal 5 Ayat (1) dan (2) Peraturan Menteri Kesehatan

7 Lihat Peraturan Menteri Kesehatan Nomor 58 Tahun 2016 tentang Sponsorship Bagi Tenaga Kesehatan.

8 Lihat Pasal 17 Kode Etik Kedokteran Indonesia. 
Nomor 58 Tahun $2016^{9}$ tentang Sponsorship bagi Tenaga Kesehatan yang menjelaskan bahwa:

“(1) Sponsorship oleh perusahaan/industri farmasi, alat kesehatan, alat laboratorium kesehatan dan/atau perusahaan/industri lainnya harus dilakukan secara terbuka dan tidak boleh ada konflik kepentingan.; (2) Sponsorship yang dilakukan secara terbuka dan tidak ada konflik kepentingan sebagaimana dimaksud pada ayat (1) dimaksudkan agar tidak mempengaruhi independensi seperti penulisan resep, anjuran penggunaan barang atau terkait produk Sponsorship".

Pemanfaatan dokter sebagai media promosi obat dalam Peraturan Menteri Kesehatan Republik Indonesia Nomor 58 Tahun 2016 Tentang Sponsorship bagi Tenaga Kesehatan boleh melakukan dengan catatan untuk kepentingan CPD (contunuing professional development) atau CME (continuing medical education).${ }^{10}$ Kerjasama yang dilakukan ini hanya untuk pengembangan profesi dokter dan pengembangan edukasi kesehatan yang diperuntukan oleh dokter untuk meneliti produk pengembangan obat yang diproduksi oleh PBF. Dapat dikatakan bahwa kerjasama yang diperbolehkan antara dokter dengan PBF dalam pemberian obat pada pasien itu kerjasama yang dilakukan secara terbuka dan tidak boleh ada konfilk kepentingan tertentu yang dilakukan oleh para pihak yang diwujudkan dengan tidak mempengaruhi independsi dokter dalam bentuk penulisan resep dan anjuran penggunaan barang atau terkait produk sponsorship pada pasien.

b. Kerjasama yang dilarang

Kerjasama yang dilakukan antara dokter dengan PBF dapat dikualifikasikan perbuatan pidana apabila suatu perbuatan tersebut memenuhi unsur yang telah dijelaskan sebelumnya dan dianggap suap dimana hal ini dalam Pasal 4 Peraturan Menteri Kesehatan Nomor 14 Tahun 2014 tentang Pengendalian Gratifikasi di Lingkungan Kementerian Kesehatan ${ }^{11}$ mengenai kerjasama yang menyatakan

\footnotetext{
9 ibid.

10 ibid.

${ }^{11}$ Lihat Peraturan Menteri Kesehatan Nomor 14 Tahun 2014 tentang Pengendalian Gratifikasi di Lingkungan Kementerian Kesehatan.
} 
bahwa, Gratifikasi yang dianggap suap sebagaimana dimaksud dalam Pasal 3 huruf a meliputi penerimaan namun tidak terbatas pada:

a. marketing fee atau imbalan yang bersifat transaksional yang terkait dengan pemasaran produk;

b. cashback yang diterima instansi yang digunakanuntuk kepentingan pribadi;

c. Gratifikasi yang terkait dengan pengadaan barang dan jasa, pelayanan publik, atau proses lainnya; dan

d. Sponsorship yang terkait dengan pemasaran atau peneltian suatu produk.

Kerjasama yang dilakukan ini merupakan kerjasama yang dikualifikasikan perbuatan pidana sesuai dengan Pasal 4 Peraturan Menteri Kesehatan Nomor 14 Tahun 2014 tentang Pengendalian Gratifikasi di Lingkungan Kementerian Kesehatan jo. Pasal 12B Undang-Undang Nomor 20 Tahun 2001 Tentang Perubahan atas Undang-Undang Nomor 31 Tahun $1999^{12}$ Tentang Pemberantasan Tindak Pidana Korupsi yaitu kerjasama antara dokter dengan PBF yang berupa perbuatan pidana seperti marketing fee, cashback, gratifikasi, dan sponsorship yang bersifat melanggar ketentuan perundang-undangan yang berlaku.

\section{Pihak-Pihak yang Dapat Dipertanggungjawabkan dalam Hubungan Dokter dengan PBF yang Mengakibatkan Kerugian}

\section{a. Pertanggungjawaban Dokter}

1. Pelanggaran Etika

Menurut Safitri bahwa pelanggaran terhadap butir-butir Kode Etik terbagi menjadi 2 (dua) jenis yaitu, pelanggaran kode etik semata-mata, dan merupakan pelanggaran etik serta sekaligus pelanggaran hukum yang dikenal dengan istilah pelanggaran etikolegal. ${ }^{13}$ Dalam hal ini dokter sebagai tenaga kesehatan yang berperan untuk memenuhi pelayanan kesehatan sesuai dengan standar dan kode etik, dipengaruhi oleh PBF melalui PBF itu sendiri atau Medical Representative-nya dalam menjalankan tugas independensi dokter, terutama dalam penulisan resep. Pasal 3 Kode Etik Kedokteran Indonesia

12 ibid.

13 Safitri Hariyani., Syahrul Macmud, Penegakan Hukum dan Perlindungan Hukum Bagi Dokter yang Diduga Melakukan Medikal Malpraktek (CV. Karya Putra Darwati 2012).[317]. 
disebutkan bahwa, "Dalam melakukan pekerjaan kedokterannya, seorang dokter tidak boleh dipengaruhi oleh sesuatu yang mengakibatkan hilangnya kebebasan dan kemandirian profesi”.

Dalam hal promosi obat, dilarang untuk menjual contoh obat yang diterima secara gratis dari PBF dan menjuruskan pasien untuk membeli obat tertentu karena dokter yang bersangkutan telah menerima komisi dari PBF tersebut. Selain itu, dalam Peraturan Konsil Kedokteran No. 4 Tahun 2011 Tentang Disiplin Profesional Dokter dan Dokter Gigi pada Pasal 3 ayat (2) huruf W menyatakan, "menerima imbalan sebagai hasil dari memberikan resep obat atau alat kesehatan merupakan pelanggaran disiplin profesional dari dokter". ${ }^{14}$

Setiap orang yang mengetahui atau kepentingannya dirugikan atas tindakan praktik dokter atau dokter gigi dapat mengadukan secara tertulis kepada Ketua Majelis Kehormatan Disiplin Kedokteran Indonesia. Majelis Kehormatan Disiplin Kedokteran Indonesia dapat memeriksa dan memberikan keputusan terhadap pengaduan yang berkaitan dengan disiplin dokter dan dokter gigi. Apabila dalam pemeriksaan ditemukan pelanggaran etika dimana dalam kasus ini berpengaruh pada etik independensi dokter dalam penulisan resep. Majelis Kehormatan Disiplin Kedokteran Indonesia dapat meneruskan pengaduan pada organisasi profesi. Sanksi disiplin dapat berupa sebagai berikut:

1. Pemberian peringatan tertulis;

2. Rekomendasi pencabutan surat tanda registrasi atau surat izin praktek;

3. Kewajiban mengikuti pendidikan atau pelatihan di institusi pendidikan kedokteran atau kedokteran gigi. ${ }^{15}$

2. Pelanggaran Hukum

Pelanggaran hukum yang dilakukan oleh dokter dalam kerjasama antara dokter dengan PBF dalam hal pemberian resep obat pada pasien dapat

\footnotetext{
${ }^{14}$ Peraturan Konsil Kedokteran No. 4 Tahun 2011 Tentang Disiplin Profesional Dokter dan Dokter Gigi, Pasal 3.

15 Peraturan Konsil Kedokteran No. 4 Tahun 2011 Tentang Disiplin Profesional Dokter dan Dokter Gigi, Pasal 63.
} 
dikenakan sanksi yang tercantum dalam Pasal 12 Peraturan Menteri Kesehatan Nomor 58 Tahun 2016 tentang Sponsorship bagi Tenaga Kesehatan yang menyatakan,

“(1) Menteri, gubernur, bupati/wali kota melakukan pembinaan dan pengawasan terhadap pelaksanaan Peraturan Menteri ini sesuai tugas dan kewenangan masing-masing.

(2) Dalam rangka pembinaan dan pengawasan sebagaimana dimaksud pada ayat (1), Menteri, gubernur, bupati/wali kota memberikan sanksi administratif kepada Tenaga Kesehatan yang melanggar Peraturan Menteri ini.

(3) Sanksi administratif sebagaimana dimaksud pada ayat (2) dapat berupa: a. teguran lisan, b. teguran tertulis; dan/atau c. pencabutan izin".

Pelanggaran hukum yang dilakukan oleh dokter sebagai tenaga kesehatan ini dalam Peraturan Menteri Kesehatan Nomor 58 Tahun 2016 tentang Sponsorship bagi Tenaga Kesehatan ini masih berbentuk sanksi administratif. Selain hal tersebut, adapun yang dapat dilakukan oleh pasien apabila mengalami kerugian yang dilakukan oleh dokter dapat mengajukan tuntutan pidana dimana bahwa seharusnya tindakan kedokteran yang dapat dibawa ke ranah hukum pidana dibatasi haya terhadap tindakan kedokteran yang mengandung kesengajaan (dolus/opzet) atas akibat yang diancamkan pidana atau tindakan kedokteran yang mengandung kelalaian nyata/berat (culpa lata). Dalam hal mengetahui sanksi pidana yang dapat diberikan pada dokter yang melakukan kerjasama antara dokter dengan PBF berdasarkan Pasal 66 Ayat (3) Undang-Undang Nomor 29 Tahun 2004 tentang Praktik Kedokteran ${ }^{16}$ menyatakan bahwa, "Pengaduan sebagaimana dimaksud pada ayat (1) dan ayat (2) tidak menghilangkan hak setiap orang untuk melaporkan adanya dugaan tindak pidana kepada pihak yang berwenang dan/atau menggugat kerugian perdata ke pengadilan”.

Bentuk kegiatan kerjasama yang dilarang tersebut antara dokter dengan PBF yang menimbulkan kerugian pada pasien terkait hal pemberian obat dapat juga dimasukkan pada kegiatan gratifikasi dimana disebutkan dalam 
Peraturan Menteri Kesehatan Nomor 14 tahun 2014 tentang Pengendalian Gratifikasi di Lingkungan Menteri Kesehatan ${ }^{17}$ yang mengatur tentang larangan penerimaan atau gratifikasi. Gratifikasi dalam Peraturan Menteri Kesehatan Nomor 14 tahun 2014 itu dibagi atas gratifikasi yang dianggap suap dan gratifikasi yang tidak dianggap suap. Dalam Peraturan Menteri Kesehatan RI Nomor 14 Tahun 2014 tentang Pengendalian Gratifikasi di Lingkungan Kementerian Kesehatan, gratifikasi dikategorikan menjadi dua, yakni gratifikasi yang dianggap suap dan gratifikasi yang tidak dianggap suap. Gratifikasi yang dianggap suap dijelaskan sebagai gratifikasi yang diterima oleh aparatur yang berhubungan dengan jabatan dan berlawanan dengan kewajiban dan tugas penerima. Sementara itu sebaliknya, gratifikasi yang tidak dianggap suap dijelaskan sebagai gratifikasi yang diterima oleh aparatur yang tidak berhubungan dengan jabatan dan tidak berlawanan dengan kewajiban dan tugas penerima. ${ }^{18}$ Gratifikasi yang dianggap suap dijelaskan pada Pasal 4 yaitu, penerimaan yang tidak terbatas pada:

“a) marketing fee atau imbalan yang bersifat transaksional dan terkait dengan pemasaran suatu produk, b) cashback yang diterima instansi digunakan untuk kepentingan pribadi, c) gratifikasi yang terkait pelayanan barang dan jasa, pelayanan publik dan lainnya, dan d) sponsorship yang terkait pemasaran dan penelitian suatu produk".

Gratifikasi yang tidak dianggap suap diatur dalam Pasal 5 yaitu, pemberian secara resmi dari aparatur kementerian sebagai wakil resmi instansi dalam suatu kegiatan dinas sebagai bentuk penghargaan, atas keikutsertaan kontribusi dalam kegiatan tersebut. Misalnya, pemberian berupa cindera mata dalam kegiatan resmi, Kedinasan seperti rapat, seminar, workshop, konferensi, pelatihan atau kegiatan lain sejenis. Kemudian, kompensasi yang diterima terkait kegitaan kedinasan, seperti honorarium, transportasi, akomodasi dan pembiayaan sebagaimana diatur pada standar biaya yang

\footnotetext{
${ }^{17}$ Peraturan Menteri Kesehatan Republik Indonesia Nomor 14 Tahun 2014 tentang Pengendalian Gratifikasi di Lingkungan Kementerian Kesehatan. 2014, Pasal 3.

18 Peraturan Menteri Kesehatan Republik Indonesia Nomor 14 Tahun 2014 tentang Pengendalian Gratifikasi di Lingkungan Kementerian Kesehatan. 2014, Pasal 4.
} 
berlaku instansi pemberi, sepanjang tidak ada pembiayaan ganda, nilai tak wajar, tidak terdapat konflik kepentingan, tidak melanggar ketentuan yang berlaku di instansi penerima. Selain itu, berdasarkan Undang-Undang Nomor 31 Tahun 1999 tentang Tindak Pidana Korupsi (Tipikor) Pasal $13^{19}$ yang menyatakan bahwa,

"setiap orang yang memberi hadiah atau janji kepada pegawai negeri dengan mengingat kekuasaan atau wewenang yang melekat pada jabatan atau kedudukannya, atau oleh pemberi hadiah atau janji dianggap melekat pada jabatan atau kedudukan tersebut, akan dipidana dengan pidana penjara paling lama 3 (tiga) tahun dan/ atau denda paling banyak 150.000.000,00 (seratus lima puluh juta rupiah)."

Adapun peraturan ini kemudian diperbaharui melalui Undang-Undang Nomor 20 Tahun 2001 tentang Perubahan Atas Undang-Undang Tipikor ${ }^{20}$. Dalam Undang-Undang tersebut, pada penjelasan pasal 12B, tertulis bahwa yang dimaksud tindak gratifikasi adalah, "pemberian dalam arti luas, yakni meliputi pemberian uang, barang, rabat (discount), komisi, pinjaman tanpa bunga, tiket perjalanan, fasilitas penginapan, perjalanan wisata, pengobatan cuma-cuma, dan fasilitas lainnya."

Gratifikasi tersebut baik yang diterima di dalam negeri maupun di luar negeri dan yang dilakukan dengan menggunakan sarana elektronik atau tanpa sarana elektronik yang berhubungan dengan jabatan atau kewenangan. ${ }^{21}$

\section{b. Pertanggungjawaban Pedagang Besar Farmasi (PBF)}

1. Pelanggaran Etika

Dalamkode etikPBF atauInternational Pharmaceutical Mananufacturer Group (IPMG) yaitu asosiasi 24 PBF yang berbasis penelitian internasioanal yang beroperasi di Indonesia dalam Pasal 4 menyatakan bahwa PBF dilarang menawarkan segala induksi, apresiasi, doorprize, insentif, dan imbalan

\footnotetext{
${ }^{19}$ Undang-Undang Nomor 31 Tahun 1999 tentang Tindak Pidana Korupsi (Tipikor), Pasal 13.

${ }^{20}$ Undang Nomor 20 Tahun 2001 tentang Perubahan Atas Undang-Undang Tipikor, Penjelasan Pasal 12B.

${ }^{21}$ Undang-Undang Republik Indonesia Nomor 20 Tahun 2001 Tentang Perubahan Atas Undang-Undang nomor 31 tahun 1999 tentang Pemberantasan Tindak Pidana Korupsi. 2001.
} 
uang kepada profesi medis. Adapun sanksi yang diberikan bagi PBF yang melakukan hal pada Pasal 4 yaitu pada Pasal 13 Kode Etik IPMG September $2019^{22}$ yang menyatakan bahwa,

“13.1. Setiap Anggota IPMG disarankan untuk secara aktif melakukan penilaian mandiri terkait pelaksanaan Kode Etik.

13.2. Melakukan pengaduan yang tulus berkaitan dengan pelanggaran Kode Etik IPMG dianjurkan. Prosedur rinci untuk pengaduan serta penanganan pengaduan (termasuk peran dan lingkup yurisdiksi IPMG) diuraikan dalam Lampiran 1: Prosedur Pelaksanaan Kode Etik IPMG.”

Jenis-jenis Pelanggaran Pelanggaran terhadap Kode Etik dikategorikan ke dalam pelanggaran ringan dan berat. Pelanggaran yang berdampak pada Anggota IPMG lain sebagai pelanggaran ringan. Contohnya, tapi tidak terbatas pada, Pemberian hadiah sebagai bagian dari budaya sopan santun, Menghambat acara ilmiah yang disponsori oleh perusahaan lain, Door prize, dll. Pelanggaran yang berdampak pada Anggota IPMG lain dan/atau pasien dan/atau reputasi IPMG dan/atau bertujuan untuk melakukan penyuapan dikategorikan sebagai pelanggaran berat. Contohnya, tapi tidak terbatas pada, Klaim tidak benar di materi promosi, Promosi off-label, Menyediakan fasilitas berlebihan untuk Profesi Kesehatan, dan Memberi imbalan uang untuk pembuatan resep obat.

Contoh-contoh di atas hanyalah sebagian dari daftar pelanggaran yang mungkin dilakukan. Daftar ini dibuat dengan maksud memberi gambaran tentang jenis-jenis pelanggaran. Sub Komite Praktik Pemasaran IPMG bersama dengan Komite Eksekutif IPMG memiliki kebebasan untuk memutuskan kategori pelanggaran tersebut.

\section{a. Pelanggaran Pertama}

"Bila Anggota IPMG melakukan pelanggaran untuk pertama kali, maka akan diambil langkah-langkah berikut:

(i) Sub Komite Praktik Pemasaran IPMG akan mengirim surat peringatan kepada General Manager (GM) perusahaan bersangkutan setelah membuat keputusan akhir dan mengikat. Tembusan diberikan kepada Sekretariat

${ }^{22}$ Lihat Kode Etik IPMG September 2019, Pasal 13. 
IPMG; dan

(ii) Selain itu, untuk pelanggaran berat, perusahaan harus membayar denda sebesar US\$2.000.”

b. Pelanggaran Kedua

"Untuk pelanggaran kedua yang dilakukan perusahaan Anggota IPMG, maka akan diambil langkah-langkah berikut:

(i) Komite Eksekutif IPMG akan mengirim surat peringatan kepada General Manager (GM) perusahaan bersangkutan jika pelanggaran termasuk pelanggaran ringan; atau

(ii) Komite Eksekutif IPMG akan mengirim surat resmi kepada Manajemen Senior di Kantor Pusat Global perusahaan yang melakukan pelanggaran, jika pelanggaran termasuk dalam kategori pelanggaran berat;

(iii) Komite Eksekutif IPMG akan mengundang GM untuk menghadiri pertemuan untuk menjelaskan tindakan perusahaan;

(iv) Anggota IPMG yang melakukan pelanggaran harus membayar denda sebesar, US\$2.000 untuk pelanggaran ringan; atau US\$5.000 untuk pelanggaran berat."

c. Pelanggaran Lebih Lanjut

"Jika anggota IPMG melakukan pelanggaran lebih lanjut/berikutnya, akan diambil langkahlangkah berikut:

(i) Komite Eksekutif IPMG akan mengirim surat resmi kepada Manajemen Senior di Kantor Pusat Global perusahaan yang melakukan pelanggaran;

(ii) Komite Eksekutif IPMG akan mengundang GM untuk menghadiri pertemuan untuk menjelaskan tindakan perusahaan; dan

(iii) Anggota IPMG yang melakukan pelanggaran harus membayar denda sebesar US\$5.000 untuk pelanggaran ringan, atau US\$20.000 untuk pelanggaran berat.

Dengan catatan bahwa Semua pembayaran denda dilakukan melalui rekening bank IPMG dalam waktu 30 hari kerja setelah menerima bukti keputusan final dan mengikat."

2. Pelanggaran Hukum

Dari ilustrasi tersebut dapat dikaitkan dengan Peraturan Menteri Kesehatan Nomor 58 Tahun 2016 tentang Sponsorship Bagi Tenaga Kesehatan, pemberian sponsorship tersebut bertujuan untuk meningkatkan pemasaran produk dari PBF lewat pemberian resep obat yang diberikan ke pasien. ${ }^{23}$ Lebih lanjut, kerjasama antara dokter dengan PBF yang mengakibatkan rugi

${ }^{23}$ Lihat Peraturan Menteri Kesehatan Nomor 58 Tahun 2016 tentang Sponsorship Bagi Tenaga Kesehatan, Pasal 3. 
pasien dalam hal pemberian obat itu susah dibuktikan dikarenakan adanya sisi kejahatan korporasi seperti yang sudah dibahas sebelumnya. Akan tetapi, Badan Pengawas Obat dan Makanan (BPOM) pada tahun 2002 telah mengantisipasi kerjasama dokter dan PBF yang dapat menimbulkan kerugian pada pasien atau kolusi dengan aturan hukum tentang 'Promosi Obat', berdasarkan Surat Keputusan (SK) Kepala BPOM No. HK.00.05.3.02706. Pasal 9 menyebutkan, ${ }^{24}$

"Industri Farmasi dan/atau Pedagang Besar Farmasi dilarang:

a. Kerja sama dengan Apotik dan Penulis Resep,

b. Kerja sama dalam pengresepan obat dengan Apotik dan/atau Penulis Resep dalam suatu program khusus untuk meningkatkan penjualan obat tertentu, dan

c. Memberikan bonus/hadiah berupa uang (tunai, bank draft, pinjaman, voucher, ticket) dan/atau barang kepada Penulis Resep yang meresepkan obat produksinya dan/atau yang didistrubusikan".

Dalam pengawasan terhadap kegiatan promosi obat oleh perusahaan farmasi dilakukan sepenuhnya BPOM dengan membentuk komisi independen. Pelanggaran terhadap Pasal 9 diatas dapat dikenakan sanksi administratif yang diatur didalam Pasal $10^{25}$ yang menyebutkan bahwa,

"Selain dapat dikenakan sanksi pidana sesuai dengan ketentuan peraturan perundang-undangan yang berlaku, terhadap Industri Farmasi dan/atau Pedagang Farmasi yang melakukan pelanggaran terhadap ketentuan sebagaimana dimaksud dalam Pasal 9 dapat dikenakan sanksi admisnistratif berupa:

a. Peringatan tertulis,

b. Penghentian sementara kegiatan,

c. Pembekuan dari/atau pencabutan izin edar obat yang bersangkutan, dan

d. Sanksi administratif lain sesuai dengan ketentuan perundang-undangan yang berlaku."

Berdasarkan Pasal 62 Ayat (1) Undang-Undang Nomor 8 Tahun 1999 tentang Perlindungan Konsumen bahwasannya pedagang besar farmasi yang melakukan kerjasama dengan dokter dalam hal pemberian obat pada

\footnotetext{
${ }^{24}$ Lihat Pasal 9 Surat Keputusan (SK) Kepala BPOM No. HK.00.05.3.02706 tentang Promosi Obat

${ }^{25}$ ibid., Pasal 10.
} 
pasien melangar ketentuan pada Pasal 13 Ayat (2) Undang-Undang Nomor 8 Tahun 2019 tentang Perlindungan Konsumen ${ }^{26}$ yaitu, "Pelaku usaha dilarang menawarkan, mempromosikan atau mengiklankan obat, obat tradisional, suplemen makanan, alat kesehatan, dan jasa pelayanan kesehatan dengan cara menjanjikan pemberian hadiah berupa barang dan/atau jasa lain".

Dalam hal ini pelaku usaha yaitu PBF melakukan promosi obat lewat dokter dan memberikan hadiah berupa barang dan/atau jasa seperti fasilitas pendukung penelitian dokter, seminar workshop dokter, jasa travel, dan masih banyak lagi yang mengakibatkan harga obat yang mahal dan pasien harus membeli obat tersebut karena sesuai dengan resep yang diberikan oleh dokter tersebut. Seperti yang telah dijelaskan di atas bahwa PBF merupakan suatu pelaku usaha yang berbentuk badan korporasi dimana untuk merumuskan terkait dengan pertanggungjawaban yang dapat dikenakan dan sanksi pidananya berdasarkan teori identifikasi korporasi sebagai perbuatan kesalahan atau mens rea itu mengacu pada badan korporasinya yaitu, PBF itu sendiri. Terkait hal tersebut adapun sanksi pidana sebagaimana dimaksud SK BPOM, Pasal 62 Ayat (1) Undang-Undang Nomor 8 Tahun 1999 tentang Perlindungan Konsumen ${ }^{27}$ menyebutkan bahwa,

"Pelaku usaha yang melanggar ketentuan sebagaimana dimaksud dalam Pasal 8, Pasal 9, Pasal 10, Pasal 13 Ayat (2), Pasal 15, Pasal 17 Ayat (1) huruf a, huruf b, huruf c, huruf e, Ayat (2) dan Pasal 18 dipidana dengan pidana penjara paling lama 5 (lima) tahun atau pidana denda paling banyak Rp. 2.000.000.000,00 (dua miliar rupiah).”

PBF sebagai korporasi dapat dikenakan sanksi pidana berupa pidana denda maupun pidana penjara. Pidana denda disini dipertanggungjawabkan bagi PBF yang melanggar ketentuan dan memberikan sponsorship pada kerjasama dengan dokter dalam hal pemberian obat pada pasien dimana dokter sebagai media promosi obat pada pasien dalam penulisan resep Ayat (2).

${ }^{26}$ Undang-Undang Nomor 8 Tahun 2019 tentang Perlindungan Konsumen, Lihat Pasal 13

${ }^{27}$ Lihat Pasal 62 Undang-Undang Nomor 8 Tahun 1999 tentang Perlindungan Konsumen. 
dokter tersebut. Pidana penjara dititikberatkan berdasarkan teori identifikasi pertanggungjawaban pidana korporasi dapat diberikan pada PBF yang dalam pengertian sempit hanya perbuatan pejabat senior (otak korporasi) yang dapat dipertanggungjawabkan kepada korporasi, namun dalam arti luas tidak hanya pejabat senior, tetapi juga agen di bawahnya. ${ }^{28}$ Sehingga dapat dikatakan pertanggungjawaban pidana korporasi yang diberikan ke PBF dalam hal kerjasama dengan dokter terkait pemberian obat pada pasien dapat diberikan kepada direktur korporasi, pejabat senior, ataupun agen yang ada dalam korporasi tersebut yang dapat dijadikan otak utama dalam perbuatan pidana tersebut.

\section{Kesimpulan}

Kerjasama adokter dengan PBF dalam pemberian obat terhadap pasien yang dapat dikualifikasikan perbuatan pidana berupa kerjasama yang dilarang dalam ketentuan pada Pasal 4 dan 5 Peraturan Menteri Kesehatan Nomor 58 Tahun 2016 tentang Sponsorship bagi Tenaga Kesehatan. Pertanggungjawaban etik dokter mengacu Pasal 3 KODEKI terkait dalam hal promosi obat, dimana dokter tersebut dapat dikenakan sanksi etik berupa pemberian peringatan tertulis, dan rekomendasi pencabutan surat tanda registrasi atau surat izin praktek. Sedangkan, pertanggungjawaban hukum dokter berupa sanksi administratif berdasarkan PMK Nomor 58 Tahun 2016 tentang Sponsorship bagi Tenaga Kesehatan dimana berupa teguran lisan, teguran tertulis, pencabutan izin dan juga sanksi pidana berdasarkan Undang-Undang Tipikor yaitu pidana denda dan pidana penjara. Selain itu, PBF dapat diberikan pertanggungjawaban etik mengacu pada Kode ETIK IPMG September 2019 dimana PBF mendapatkan teguran secara lisan dan tertulis, pencabutan izin dan juga sanksi denda. Sedangkan, pertanggungjawaban hukum mengacu pada PMK Nomor 1148/MENKES/PER/VI/2011 Tentang Pedagang Besar Farmasi yaitu sanksi administrasi berupa peringatan, penghentian sementara,

\footnotetext{
${ }^{28}$ Muladi dan Dwidja Priyatno, Op Cit.[180].
} 
pencabutan pengakuan, dan pencabutan izin dan sanksi pidana berupa pidana denda dan pidana penjara berdasarkan Pasal 62 Ayat (1) UU No. 8 Tahun 1999 tentang Perlindungan Konsumen.

\section{Daftar Bacaan}

\section{Buku}

Agus Yudha Hernoko, Hukum Perjanjian Asas Prporsionalitas Dalam Kontrak Komersial (Kencana 2011).

Andi Hamzah, Bunga Rampai Hukum Pidana dan Acara Pidana (Ghalia Indonesia 2001).

Andi Hamzah, Asas - Asas Hukum Pidana (Rineka Cipta 2008).

Barda Nawawi Arief, Masalah Penegakan Hukum dan Kebijakan Penanggulangan Kejahatan (Citra Aditya Bakti 2001).

Departemen Pendidikan Nasional (Pusat Bahasa Indonesia), Kamus Besar Bahasa Indonesia, edisi ke empat (Gramedia Pusaka Umum 2008).

Didik Purwoleksono Hendro, Hukum Pidana, (Airlangga University Press 2013).

Hamzah Hatrik, Asas Pertanggungjawaban Korporasi dalam Hukum Pidana Indonesia (strictliability dan various liability) (Raja Grafindo Persada 1996).

Hartanti, Tindak Pidana Korporasi (Sinar Grafika 2005).

Mardjono, Pertanggungjawaban Pidana Korporasi (Universitas Diponegoro 1987).

Moeljatno, Asas-asas Hukum Pidana (Rineka Cipta 1993).

Muladi dan Barda Nawawi Arief, Teori-Teori dan Kebijakan Pidana (Alumni 2005).

Muladi dan Dwidja Priyatno, Pertanggungjawaban Pidana Korporasi,

Pamudji, Kerjasama Antar Daerah 1985).

Peter Mahmud Marzuki, Penelitian Hukum (Kencana Prenada Media Group 2005).

Peter Mahmud Marzuki, Pengantar Ilmu Hukum ( 2013).

P.A.F. Lamintang, Dasar-Dasar Hukum Pidana Indonesia (Citra Adityta Bakti, 1996). 
Pipin Syarifin, Hukum Pidana di Indonesia (Pustaka Setia, 2000).

Roestiyah, Strategi Belajar Mengajar (Rineka Cipta 2014).

Safitri Hariyani., Syahrul Macmud, Penegakan Hukum dan Perlindungan Hukum Bagi Dokter yang Diduga Melakukan Medikal Malpraktek, Cetakan Pertama (Karya Putra Darwati 2005).

Wirjono Prodjodikoro, Perbuatan Melanggar Hukum, Vorking-Von Hoeve. (Bandung,

\section{Jurnal}

Sri Pujiastuti, 'Kerjasama pemasaran obat antara dokter dan pedagang besar farmasi di kota bandung, dihubungkan dengan kode etik kedokteran dan kepmenkes no 3987/a/k/1973' (2004) XII Mimbar.

Syukron, 'Perkembangan Doktrin Perbuatan Melawan Hukum Penguasa', (2018) 1 Nurani Hukum.

Wendi Muh. Fadhli, Siti Anisah, 'Tanggungjawab Hukum Dokter dan Apoteker dalam Pelayanan Resep’, (2016) 13 Media Farmasi.

Yenny, Fitri Z. 'Tinjauan Hukum Dokter yang Berkolusi dengan Perusahaan Farmasi dalam Meresepkan Obat', (2018) 3 Cendekia Hukum.

\section{Laman}

Aziz, Sriana, 'Analisis Komponen Harga Obat'. (BuletinPenelitianKesehatan, 2000), Tersedia pada: <http://ejournal.litbang.depkes.go.id/index.php/BPK/ article/view/2051/1232> diakses pada tanggal 27 Mei 2019.

Harmono,'Kerjasama Dokter dengan Perusahaan Farmasi Melanggar Kode Etikkah?' (Jawa Tengah: SuaraJateng, 2013) Tersedia pada: <http://www. suarajateng.com/2013/02/kerjasama-dokter-dengan-perusahaan.html $>$ diakses tanggal 25 Mei 2019.

Ichsan, Muhammad, 'Mengakhiri Kolusi Dokterdan Perusahaan Farmasi', (Jakarta: HukumOnline, 2008) Tersedia pada: <https://www.hukumonline.com/berita/ baca/hol18808/mengakhiri-kolusi-dokter-dan-perusahaan-farmasi-/> diakses pada tanggal 25 Mei 2019.

Thabrany, Hasbullah. 'Biaya Obat Bagi Peserta Askes di Berbagai Klinik RSCM'. (Jakarta, Berita UI 2015) Tersedia pada: http://staff.ui.ac.id/system/files/users/ hasbulah/material/biayaobatpesertaaskesdirscm.pdf diakses tanggal 23 Mei 2019. 
Wathoni, Nasrul, 'Lingkaran Terlarang Perusahaan Farmasi-MedRep - Praktisi Kesehatan dalam Dunia Distribusi Obat', (Kompasiana.com, 2016) Tersedia pada: $\quad<$ https://www.kompasiana.com/nasrulwathoni/lingkaran-terlarangperusahaan-farmasi-medrep-praktisi-kesehatan-dalam-dunia-distribusi-obat $>$ diakses tanggal 23 September 2019.

, Tersedia pada: <https://www.kaskus.co.id/ thread/5472c402dc06bd35488b456a/pengakuan-mantan-medrep-banyakapoteker-tertawa-melihat-resep-si-dokter/> diakses tanggal 18 Oktober 2019.

, Tersedia pada: $<$ https://www.hukumonline.com/klinik/detail/ ulasan/lt4da27259c45b9/di-mana-pengaturan-kerugian-konsekuensialdalam-hukum-indonesia-/> diakses tanggal16 Oktober 2019.

\section{Perundang-undangan}

Undang - Undang Dasar Republik Indonesia Tahun 1945.

Kitab Undang - Undang Hukum Pidana (KUHP) Indonesia.

Undang - Undang Nomor 419 Tahun 1949 Tentang Hukum.

Ordonansi Obat Keras (Sterkwerkende Geneesmiddelen Ordonanntie Staatsblad 1949:419).

Undang - Undang Republik Indonesia Nomor 8 Tahun 1999 Tentang Perlindungan Konsumen (Lembaran Negara Republik Indonesia Tahun 1999 Nomor 42).

Undang - Undang Nomor 39 Tahun 1999 Tentang Tentang Hak Asasi Manusia, (Lembaran Negara Republik Indonesia Tahun 1999 Nomor 165; Tambahan Lembaran Negara Republik Indonesia Nomor 3886).

Undang - Undang Nomor 29 Tahun 2004 Tentang Praktik Kedokteran, (Lembaran Negara Republik Indonesia Tahun 2004 Nomor 116, Tambahan Lembaran Negara Republik Indonesia 4431).

Undang-Undang Nomor 36 Tahun 2009 Tentang Kesehatan, (Lembaran Negara Republik Indonesia Tahun 2009 Nomor 144, Tambahan Lembaran Negara Republik Indonesia Nomor 5063).

\section{Keputusan Presiden}

Keputusan Presiden Nomor 12 Tahun 1994 Tentang Badan Pertimbangan Kesehatan Nasional. 
Keputusan Presiden Nomor 56 Tahun 1995 Tentang Majelis Disiplin Tenaga Kesehatan.

\section{Peraturan Pemerintah}

Peraturan Pemerintah Nomor 31 Tahun 1996 Tentang Tenaga Kesehatan.

Peraturan Pemerintah Nomor 51 Tahun 2009 Tentang Pekerjaan Kefarmasian.

\section{Peraturan Menteri Kesehatan RI}

PMK Nomor 2052/MENKES/PER/X/2011 Tentang Izin Praktik dan Pelaksanaan Praktik Kedokteran.

PMK No. 1148/MENKES/PER/VI/2011 Tentang Pedagang Besar Farmasi.

PMK Nomor 63 Tahun 2014 Tentang Pengadaan Obat Berdasarkan Katalog Elektronik (E-Catalogue).

PMK Nomor 14 Tahun 2014 Tentang Pengendalian Gratifikasi di Lingkungan Kementerian Kesehatan.

PMK Nomor 58 Tahun 2016 Tentang Sponsorship Bagi Tenaga Kesehatan.

PMK Nomor 30 Tahun 2017 Tentang Perubahan Kedua atas PMK Nomor 1148/ MENKES/PER/VI/2011 Tentang Pedagang Besar Farmasi.

\section{Keputusan Menteri Kesehatan}

Keputusan Menteri Kesehatan Republik Indonesia Nomor 3987/A/Sk/1973 Tentang larangan pedagang besar farmasi menjual obat langsung kepada Dokterdokter, Dokter Gigi, dan Apoteker.

Keputusan Menteri Kesehatan Republik Indonesia No.1191/Menkes/PSK/IX/2002 Tentang Perubahan atas Kepmenkes No.918/Menkes/Per/X/1993 Tentang Pedagang Besar Farmasi.

\section{Kode Etik}

Kode Etik Kedokteran Indonesia dan Pedoman Pelaksanaan Kode Etik Kedokteran Indonesia, Majelis Kehormatan Etik Kedokteran Indonesia (MKEK) dan Ikatan Dokter Indonesia (IDI).

Kode Etik IPMG Tentang Praktik Pemasaran Produk Farmasi di Indonesia Revisi September 2019. 
1802 Herninta Lagoon: Kerjasama Dokter dengan

\section{Surat Edaran}

Surat Edaran Nomor KF/MENKES/167/III/2014 Tentang Pengadaan Obat Berdasarkan Katalog Elektronik (E-Catalogue) 